\title{
SPEECH RECOGNITION APLIKASI KAMUS BAHASA SASAK BERBASIS ANDROID
}

\author{
Yuliadi $^{1 *}$, Rusdan ${ }^{2}$, Rodianto $^{3}$, \\ ${ }^{1,3}$ Program Studi Teknik Informatika \\ Fakultas Teknik UTS Sumbawa \\ J1. Raya Olat Maras, Moyo Hulu, Nusa Tenggara Barat. 84371 \\ *E-mail: yuliadi@uts.ac.id \\ ${ }^{2}$ Program Studi Sistem Informasi \\ Fakultas Teknik Universitas Nahdlatul Ulama NTB \\ Jl. Pendidikan No.06, Mataram, Nusa Tenggara Barat. 83125
}

\begin{abstract}
Abstrak: Bahasa merupakan bagian penting dari suatu negara maupun wilayah dalam berkomunikasi antar individu secara formal maupun informal. Namun menjadi kendala ketika pihak luar berinteraksi dengan masyarakat asli suatu daerah, salah satunya bahasa Sasak Pulau Lombok, Nusa Tenggara Barat. Selain itu, dalam pertemuan formal dan informasional, bahasa Sasak jarang digunakan dalam berkomunikasi. Berdasarkan permasalahan tersebut, diperlukan suatu media yang membantu dalam berinteraksi berupa kamus. Kamus Bahasa Sasak dihadirkan dalam teknologi smartphone android dengan memanfaatkan suara sebagai inputnya. Aplikasi dibangun dengan menggunakan metodologi prototipe dan tools pemrograman menggunakan Pemrograman Embarcadero Delphi 10.32 dan SQLite sebagai database. Hasil dari penelitian ini adalah membangun Aplikasi Speech Recognition Kamus Bahasa Sasak berbasis android dengan memanfaatkan input suara.
\end{abstract}

Kata Kunci: android, bahasa, database, prototipe, smartphone

\section{PENDAHULUAN}

$\mathrm{B}$ ahasa merupakan salah satu ciri khas sebuah negara maupun daerah tertentu sebagai cerminan jati diri dapat diakui oleh negara maupun daerah lainnya. Di Indonesia, banyak sekali bahasa daerah yang sebagai ciri khas yang berbeda di setiap daerah, seperti Bahasa Sasak (Nisa', 2016). Bahasa Sasak adalah Bahasa yang sehari-sehari untuk komunikasi dipakai oleh Suku Sasak di Pulau Lombok Provinsi Nusa Tenggara Barat. Pulau Lombok merupakan wilayah yang didiami suku sasak yang sudah berabad-abad. Ada pendapat yang mengatakan bahwa orang Sasak berasal dari percampuran antara penduduk asli Lombok dengan para pendatang dari Jawa (Rafsanjani, 2019).

Menurut Depdiknas (2005), bahasa adalah ucapan pikiran dan perasan manusia secara teratur, yang mempergunakan bunyi sebagai alatnya. Sedangkan menurut Rasyid et al. (2009), bahasa merupakan sebuah ucapan yang struktur dan makna bebas, sebagai tanda menyimpulkan tujuan (Pebrijayanti, 2018). Pada intinya, fungsi dari bahasa sebagai alat komunikasi untuk mengekspresikan diri dalam beradaptasi dan alat kontrol sosial pada lingkungan tertentu (Maslan et al., 2016).

Bahasa Sasak adalah salah satu bahasa daerah di Indonesia yang digunakan dalam berkomunikasi oleh masyarakat suku Sasak di Pulau Lombok. Secara administratif, bahasa Sasak digunakan oleh empat kabupaten dan satu kota, yakni Lombok Barat, 
Lombok Tengah, Lombok Timur, Lombok Utara, dan Kota Mataram. Dialek bahasa Sasak secara fundamental tidak mengikuti wilayah administratif tersebut. Bahasa Sasak yang digunakan di Lombok secara dialek dan lingkup kosakatanya dapat digolongkan ke dalam beberapa bahasa sesuai dengan wilayah penuturnya: Meriak-Meriku (Lombok Selatan), Meno-Mene dan Ngeno-Ngene (Lombok Tengah), Ngeto-Ngete (Lombok Tenggara), dan Kuto-Kete (Lombok Utara). Ada empat dialek yang umum digunakan oleh daerah di Lombok yakni Dialek Pejanggik (Lombok Tengah), Dialek Petung Bayan (Lombok Utara), Dialek Selaparang (Lombok Timur dan Lombok Barat), dan Dialek Pujut (Lombok Tengah) (Sarwadi et al., 2019).

Saat ini, masyarakat Sasak sangat jarang menggunakan bahasa Sasak dalam pertemuan resmi sekalipun yang hadir di tempat itu hanya kelompok etnis Sasak. Bahkan pada saat pertemuan masyarakat adat Sasak, tokoh-tokoh masyarakat Sasak dalam memberikan sambutan seringkali menggunakan bahasa Indonesia (Mugni, 2016). Untuk melestarikan Bahasa Sasak dibutuhkan sebuah media penerjemah yang berjalan dalam sistem operasi android.

Dalam berinteraksi oleh setiap daerah diperlukan suatu instrument (alat) untuk menerjemahkan kosa kata. Salah satu instrumen yang bisa digunakan sehingga perbedaan bahasa tidak menjadi kendala dalam berinteraksi untuk membantu dalam komunikasi adalah kamus (Sofya et al., 2017). Penyajian kamus haruslah sesuai dengan teknologi yang berkembang pada masyarakat Indonesia pada umumnya yakni smartphone (Muhammad et al., 2019). Saat ini teknologi smartphone berbasis sistem operasi android sudah banyak penggunanya di dunia, salah satunya negara Indonesia. Salah satu fitur smartphone adalah speech recognition atau speech to text digunakan untuk memudahkan penguna dalam memanfaatkan mengunakan suara untuk menjalankan aplikasi smartphone tanpa menggukan keyboard.

Speech recognition merupakan sebuah proses komputer untuk melakukan identifikasi suara yang diucapkan oleh pengguna tanpa identitas terkait. Dalam aktivitasnya speech recognition menjalankan aplikasi komputer dengan menggunakan suara sebagai masukan dengan parameter yang pengucapan dan tingkat penekanan suara yang dicocokkan dengan template database yang tersedia (Andriana et al., 2016).

Pada umumnya, speech recognition memproses sinyal suara yang masuk dan menyimpannya dalam bentuk digital. Hasil proses digitalisasi dikonversi ke dalam bentuk spektrum suara yang akan dianalisa dengan membandingkannya dengan template suara pada database sistem (Andriana et al., 2016). Dengan pemanfaatan speech recognition pada aplikasi penerjemah Bahasa Sasak sesuai dengan perkembangan teknologi smartphone pada masyarakat umunya.

Andriana et al. (2016) melakukan penggabungan speech recognition dengan teknologi kendali elektronik sebagai pengganti fungsi mouse menggunakan suara. Speech recognition yang melakukan mengkonversi bahasa lisan ke dalam input data kemudian sistem akan mengidentifikasi kata yang diucapkan. Penelitian yang dilakukan oleh Jaya (2016), penerapan speech recognition pada permainan teka-teki silang menggunakan metode hidden markov model (HMM) berbasis desktop. HMM mengidentifikasi ucapan user berupa huruf-huruf yang memiliki arti. Penelitian yang dilakukan oleh Khairunizam (2017) memanfaatkan speech recognition dalam memutar musik dengan pencarian menggunakan pengucapan suara dan mengontrol musik di antaranya perintah sebelumnya, selanjutnya, berhenti, mainkan, dan keluar. Dan penelitian yang dilakukan oleh Muhammad (2019), Speech Recognition pada aplikasi Kamus Bahasa Indonesia- 
Sumbawa dengan menggunakan suara sebagai input dalam proses penerjemahan Bahasa Sumbawa-Bahasa Indonesia dan sebaliknya (Muhammad et al., 2019).

Tujuan dari penelitian yang dilakukan oleh peneliti adalah untuk melakukan pengembangan speech recognition aplikasi kamus Bahasa Sasak berbasis android yang dapat dimanfaatkan oleh masyarakat Suku Sasak pada khususnya dan masyarakat luar pada umumnya sebagai penerjemah Bahasa Sasak. Diharapkan aplikasi ini sebagai media interaksi yang dimanfaatkan masyarakat asli dan masyarakat luar dalam berkomunikasi. Serta sebagai media untuk melestarikan Bahasa Sasak yang menjadi warisan kebudayaan.

\section{METODE PENELITIAN}

Metode penelitian merupakan suatu aktivitas yang berupa tahapan-tahapan yang dilaksanakan dalam penelitian untuk menghasilkan output sesuai dengan keinginan. Diagram metode penelitian yang digunakan oleh penulis ditunjukkan pada Gambar 1.

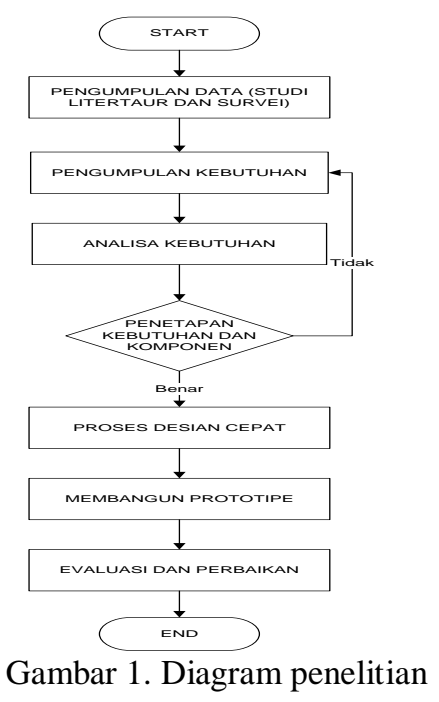

Dalam penelitian ini, penulis menerapakan dua metode penelitian, diantaranya adalah sebagai berikut:

a. Metode Pengumpulan Data

Metode pengumpulan data adalah tahap awal yang dilakukan dalam penelitian dengan aktivitas untuk mencari informasi terkait pemecahan permasalahan. Kegiatan tersebut berupa studi literatur dan survei. Studi literatur sebagai referensi dasar dalam penelitian sedangkan survei sebagai metode yang digunakan untuk mendapatkan datadata yang digunakan untuk mendefinisikan kebutuhan sistem.

b. Metode Pengembangan

Metode pengembangan yang digunakan oleh penulis adalah prototipe yang menerapkan model fisik kerja sistem sebagai versi awal dari sistem dengan langkahlangkah yang diadopsi dalam penelitian ini, yakni:

(1) Pengumpulan Kebutuhan

Kegiatan pengumpulan kebutuhan yang aktivitas melibatkan pertemuan antara pengembang dan pelanggan untuk menentukan tujuan secara menyeluruh sesuai kebutuhan perangkat lunak yang dibuat. Dalam implementasi mengumpulkan kebutuhan mengidentifikasi kebutuhan berupa garis besar kebutuhan dasar dari sistem yang akan dibuat. Kegiatan tersebut dilakukan pengembang dalam bentuk survei. 
(2) Proses desain cepat berfokus pada representasi kebutuhan pengguna berdasarkan aspek perangkat lunak dari sudut pengguna yang mencakup input, proses dan output. Adapun hasil proses desain cepat tersebut adalah:

a) Use Case Diagram

Use case diagram merupakan gambaran awal dari proses sistem Speech Recognition Aplikasi Kamus Bahasa Sasak berbasis android yang dibangun, menampilkan beberapa aktor yang terlibat dalam hal ini admin yang memasukan kosakata dari aplikasi dan user sebagai pengguna biasa. Gambaran use case diagram Speech Recognition aplikasi kamus Bahasa Sasak berbasis android ditunjukkan pada Gambar 2 .

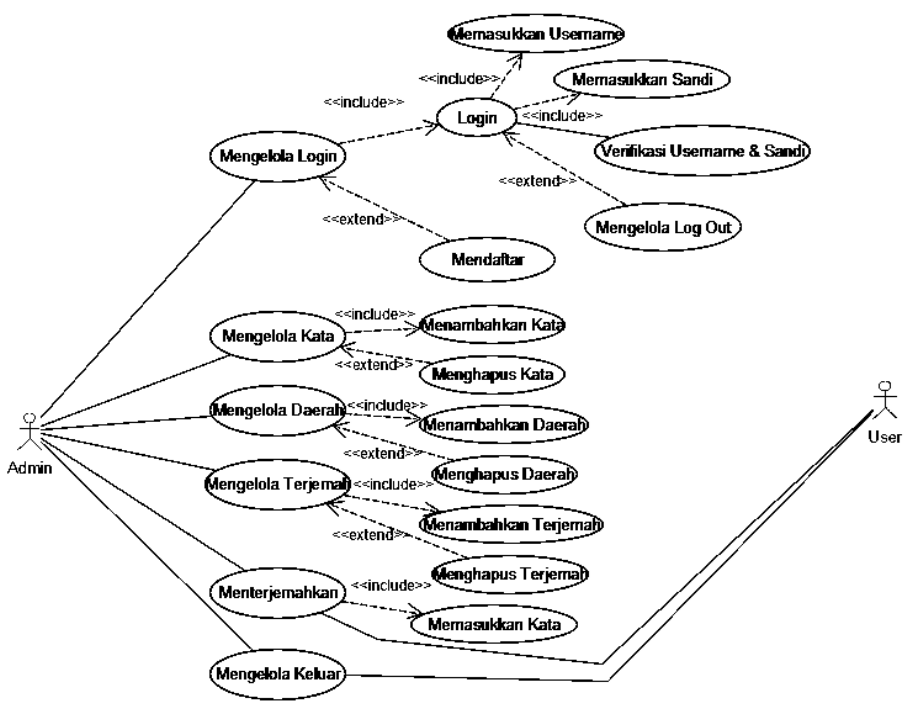

Gambar 2. Use Case Diagram

b) Activity Diagram

Activity diagram merupakan gambaran aktivitas dari sistem Speech Recognition aplikasi kamus Bahasa Sasak berbasis android yang dibangun dimana menampilkan awal aktivitas yanag dikerjakan oleh masing-masing aktor hingga berakhir pada aktor tertentu. Gambaran activity diagram Speech Recognition aplikasi kamus Bahasa Sasak berbasis android ditunjukkan pada Gambar 3.

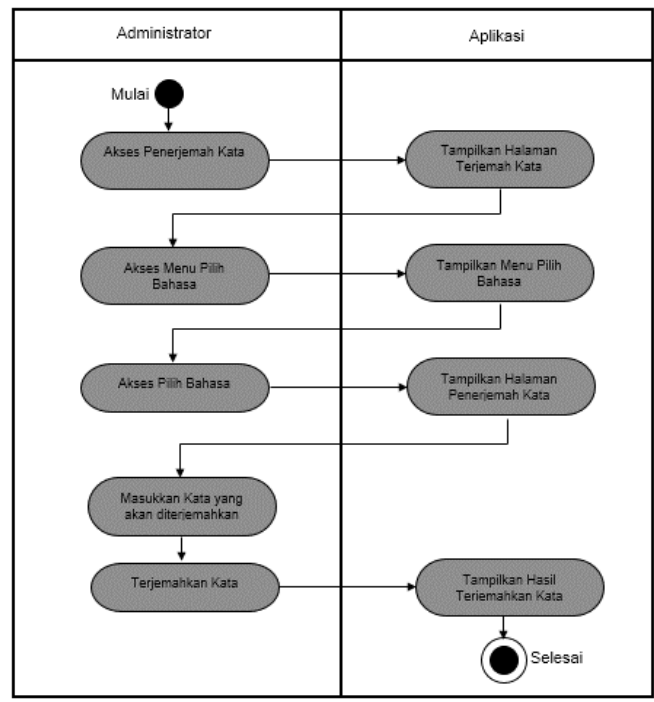

Gambar 3. Acivity Diagram 


\section{c) Class Diagram}

Class diagram adalah sebuah proses menggambarkan struktur class berupa identitas kelas lengkap dengan atribut dan metodenya serta hubungan satu sama lain dari Speech Recognition aplikasi kamus Bahasa Sasak daerah berbasis android. Gambaran class diagram Speech Recognition aplikasi kamus Bahasa Sasak berbasis android ditunjukkan pada Gambar 4.

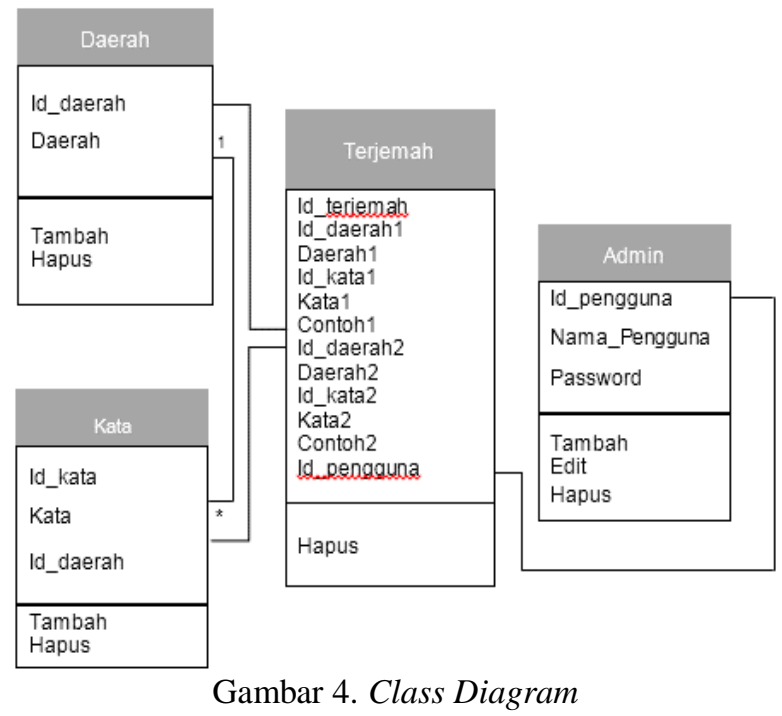

\section{HASIL DAN PEMBAHASAN}

Speech Recognition merupakan suatu proses mengolah suara digital yang dikontrol dengan aplikasi untuk mengenali adanya perintah suara yang dideteksi. Teknologi ini bekerja dengan menangkap suara manusia yang diubah menjadi format digital dan diterjemahkan dalam suatu sistem dengan membandingkan informasi masukkan yang sudah berupa format digital tersebut yang selanjutnya menjalankan suatu instruksi tersebut (Vincent \& Satwika, 2020). Proses Speech Recognition dengan merubah sinyal analog menjadi sinyal digital. Proses untuk mengenali dan memahami kata-kata yang diucapkan oleh satu orang atau banyak orang yang diinputkan melalui mikrofon (ASR). Kemudian melakukan identifikasi untuk mengenali apa yang diucapkan oleh penggunanya. ASR adalah singkatan dari Automatic Speaker Recognition yang digunakan untuk mengenali seseorang dari frasa yang diucapkan (Aditya et al., 2020).

Aplikasi merupakan sebuah program komputer yang digunakan digunakan untuk melaksanankan fungsi sesuai dengan masukan yang diberikan oleh pengguna untuk mencapai sasaran yang akan dituju. Atau aplikasi adalah media pemecahan masalah dengan menggunakan teknik pemrosesan data yang berpacu pada sebuah komputansi sesuai pemrosesan data yang diharapkan (Erlinda, 2020). Sedangkan android merupakan salah satu sistem operasi untuk telepon seluler yang berbasis Linux yang menyediakan platform terbuka bagi para pengembang aplikasi untuk membuat bermacam peranti bergerak. Antarmuka pengguna android umumnya berupa manipulasi langsung, menggunakan gerakan sentuh, misalnya menggeser, mengetuk, untuk memanipulasi objek di layar, serta keyboard virtual untuk menulis teks (Koalu, 2019).

Metode pengembangan yang digunakan oleh penulis adalah prototype. Prototype merupakan salah satu metode pengembangan perangat lunak, yang menerapkan model fisik kerja sistem sebagai versi awal dari sistem sendiri. Adapun langkah-langkah dalam 
prototyping, yakni pengumpulan kebutuhan, proses desain cepat, membangun prototipe dan evaluasi dan perbaikan (Purnomo, 2017).

Delphi merupakan aplikasi pemrograman turunan dari bahasa pascal dikenal dengan Embarcadero Delphi. Pemrograman Delphi merupakan lingkungan pengembangan terintegrasi untuk aplikasi Microsoft Windows, awalnya dikembangkan oleh Borland dan sekarang dimiliki Embarcadero Technologies (Khairunnazri et al., 2020).

SQLite Database adalah suatu sistem operasi android yang digunakan untuk membuat relational database. SQLite sebagai Database Manajemen Sistem (DBMS) yang digunakan mengelola database dalam pengembangan aplikasi kamus Bahasa Sasak android ini (Khairunnazri et al., 2020).

Berikut uraian hasil implementasi dari Speech Recognition aplikasi kamus Bahasa Sasak berbasis android dalam bentuk antar muka sebagai media interaksi dengan pengguna. Hasil tersebut adalah:

a. Halaman Utama

Halaman utama Speech Recognition aplikasi kamus Bahasa Sasak berbasis android adalah tampilan awal yang muncul ketika pengguna membuka aplikasi tersebut. Tampilan antar muka halaman utama Speech Recognition aplikasi kamus Bahasa Sasak berbasis android ditunjukkan pada Gambar 5.

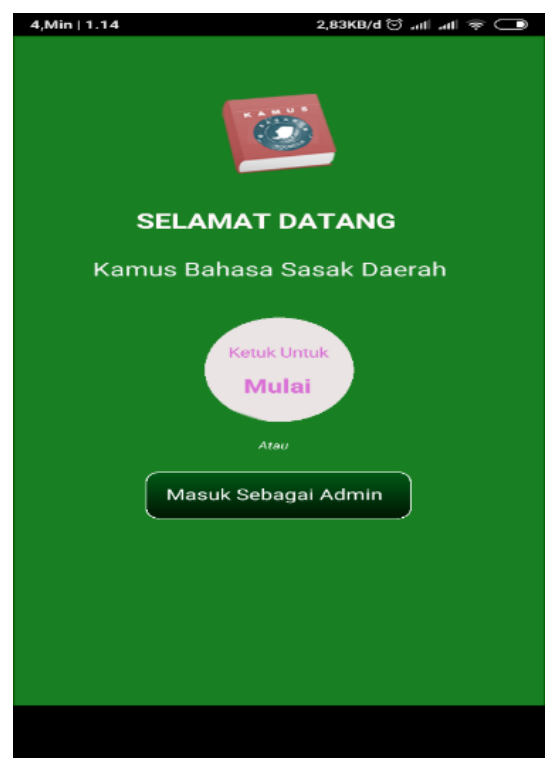

Gambar 5. Halaman utama

b. Halaman Admin

Halaman Menu Admin adalah halaman yang digunakan pengelola aplikasi untuk memasukkan pengetahuan yang dibutuhkan aplikasi. Halaman ini terdiri dari submenu penerjemah (kamus), tambah dan hapus kata, tambah dan hapus daerah, tambah dan hapus terjemah dan dan logout. Tampilan antar muka halaman utama Speech Recognition aplikasi kamus Bahasa Sasak berbasis android ditunjukkan pada Gambar 6. 


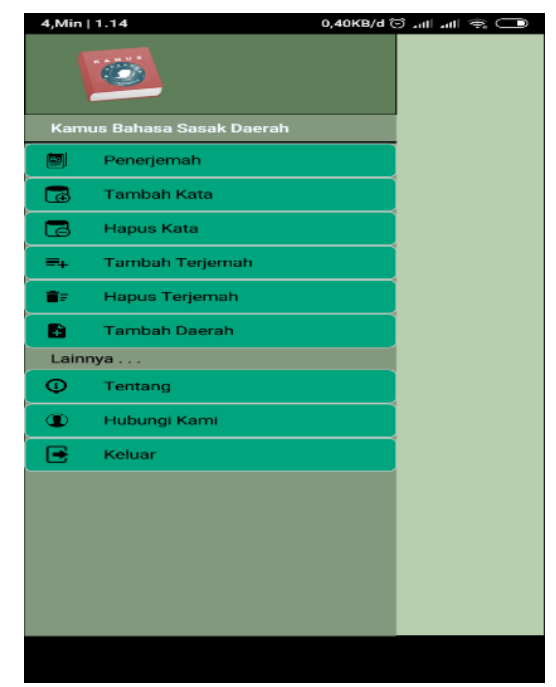

Gambar 6. Halaman menu admin

c. Halaman Penerjemah

Halaman penerjemah adalah halaman yang terpenting dari Speech Recognition aplikasi kamus Bahasa Sasak berbasis android. Halaman ini diakses oleh pengguna untuk menemukan arti kata dari kata yang akan dicari terjemahannya. Tampilan antar muka halaman penerjemah Speech Recognition aplikasi kamus Bahasa Sasak berbasis android ditunjukkan pada Gambar 7.

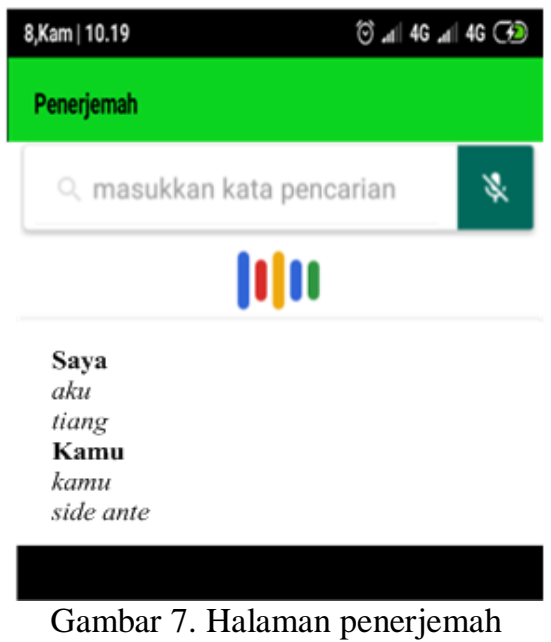

\section{KESIMPULAN}

Dari hasil penelitian dan pembahasan yang telah dilakukan, penulis mengambil kesimpulan, yakni telah dibuat sebuah Speech Recognition aplikasi kamus Bahasa Sasak Daerah berbasis android, untuk membantu masyarakat berkomunikasi dengan mengetahui arti kata dari setiap dialek yang ada di Pulau Lombok. Aplikasi kamus bahasa sasak yang dapat bekerja dengan memanfaatkan suara sebagai inputan yang akan diproses tanpa pengguna memanfaatkan keyboard sebagai alat masukan. Selain itu, aplikasi kamus Bahasa Sasak ini dapat membantu pengguna dalam menerjemahkan Bahasa Indonesia ke Bahasa Sasak. Dalam sistem pengenalan suara, banyak faktor yang memengaruhi akurasi diantaranya intonasi suara dan kebisingan (noise). Aplikasi berkerja dengan baik sesuai dengan yang diperintahkan mengunakan suara tanpa koneksi internet. 


\section{DAFTAR PUSTAKA}

Aditya, R., Muid, A., \& Ristian, U. (2020). Tempat sampah otomatis speech recognition menggunakan pocketsphinx. Jurnal Ilmiah Informatika, 15(1), 39-46.

Andriana; Olly V; Riyanto S; Ganjar T; Zulkarnain. (2016). Speech Recognition sebagai fungsi mouse untuk membantu pengguna komputer dengan keterbatasan khusus. Prosiding Seminar Nasional Sains dan Teknologi. Jakarta: 8-9 November 2016.

Erlinda, M. (2020). Perancangan aplikasi mobile kamus istilah komputer untuk mahasiswa baru bidang ilmu komputer berbasis android. Jurnal Teknologi dan Open Source, 3(1), 30-43.

Jaya, M.T.S., D. Puspitaningrum., \& B. Susilo. (2016). Penerapan Speech Recognition Pada permainan teka-teki silang menggunakan metode Hidden Markov Model (HMM) berbasis desktop. Jurnal Rekrusif, 4(1), 119-129.

Khairunizam., Danuri., \& Jaroji. Jurnal INOVTEK Polbeng-Seri Informatika, 2(2), 97-104. https://doi.org/10.35314/isi.v2i2.196.

Khairunnazri., Muh. Fahrurrozi., \& L.P.I. Kharisma. (2020). Aplikasi kamus bahasa sasak halus menggunakan android. TEKNIMEDIA: Teknologi Informasi dan Multimedia, 1(1), 28-33. https://doi.org/10.46764/teknimedia.v1i1.11.

Maslan, A., Setiono, Y., \& Alfazri, F. (2016). Pengembangan Smart Application Translation Aneka Bahasa Sulawesi Berbasis Android. Jurnal Nasional Teknolohi dan Sistem Informasi, 02(01), 55-64.

Mugni. (2016). Pemertahanan bahasa sasakpada keluarga bangsawan Lombok (Studi etnografi di Kabupaten Lombok Timur). Jurnal Lingustik, Satra dan Pendidikan (JURNALISTRENDI), 1(1), 111.

Muhammad, Hidayat, S., \& Amrullah, A. Z. (2019). Speech recognition untuk aplikasi kamus Bahasa Indonesia-Sumbawa berbasis android. Jurnal Bumigora Information Technology (BITe), 1(2), 126137. https://doi.org/10.30812/bite.v1i2.606.

Nisa', Q. (2016). Pelestarian Bahasa Daerah (Sasak) di Sekolah, Wujud Mempertahankan Kearifan Lokal. Kompasiana. /pelestarian-bahasa daerah

Oktaviano Koalu, S. R. U. A. S. (2019). Rancang bangun aplikasi pengenalan bahasa tountemboan menggunakan speech recognition. Jurnal Teknik Informatika, 14(2), 269-278. https://doi.org/10.35793/jti.14.2.2019.24003

Purnomo, D. (2017). Model Prototyping Pada Pengembangan Sistem Informasi. J.I.M.P - Jurnal Informatika Merdeka Pasuruan, 2(2), 54-61. https://doi.org/10.37438/jimp.v2i2.67.

Rafsanjani. (2019). Sasak, Suku di NTB Yang Menjadi Ikon Kebudayaan Lombok. Mobil Lombok. https://mobillombok.com/info-lombok/suku-sasak-nusa-tenggara-barat.html.

Riska Pebrijayanti, Z. A. (2018). Perancangan Aplikasi Mobile Kamus Istilah Komputer Untuk Mahasiswa Baru Bidang Ilmu Komputer Berbasis Android. 4(1), 57-64.

Sarwadi, G., Mahsun, M., \& Burhanuddin, B. (2019). Lexical ariation of Sasak Kuto-Kute Dialect in North Lombok District. Jurnal KATA, 3(1), 155-169. https://doi.org/10.22216/kata.v3i1.4142.

Sofya, N. D., Esabella, S., \& Rodianto. (2017). Rancang bangun aplikasi kamus bahasa Sumbawa berbasis android. Jurnal Matrik, 17(1), 36-45. https://doi.org/10.30812/matrik.v17i1.59.

Vincent, W.A., I.P. Satwika, A. A. A. P. Ardyanti. (2020). Implementasi Speech Recognition dalam melakukan automasi pada perangkat elektronik rumah menggunakan esp8266. Progresif: Jurnal Ilmiah Komputer, 16(1): 13-24. 